\title{
INSTITUTIONAL ASPECTS OF HEALTH AND SAFETY AT WORK IN POLAND
}

doi: $\quad 10.2478 /$ czoto-2019-0031

Date of submission of the article to the Editor: 10/11/2018

Date of acceptance of the article by the Editor: 13/01/2019

Ewa Kozień ${ }^{1}$ - orcid id: 0000-0002-5876-2804

Adam Kozień ${ }^{2}$ - orcid id: 0000-0002-9301-9645

${ }^{1}$ Cracow University of Economics, Poland, koziene@uek.krakow.pl

2Jagiellonian University in Cracow, Poland

Abstract: Health and safety at work have their legal basis in international and Polish law - source of law currently valid in Poland. For efficiently functioning system of health and safety at work it is necessary to build appropriate institutional environment. The purpose of the article is to analyse the institutional system of health and safety at work in Poland based on source of law currently valid in Poland and forming remarks de lege lata and de lege ferenda in this scope.

Keywords: law, health and safety

\section{INTRODUCTION}

Work is an inseparable element of human life, however, it cannot lead to a situation in which the very life or health of a human being would be uncontrollably put at direct risk e.g. heavy metals exposure (Ulewicz et al., 2010; Radzyminska-Lenarcik and Ulewicz, 2014) or high pressure exposure (Pobedza and Sobczyk, 2013; Walczak and Sobczyk, 2014). Each work carries with it certain risk and hazard to life, or even the human life, but it should be maximally minimalized e.g. by use of more durable materials (Szabracki and Lipinski, 2014; Mazur and Mikova, 2016), properly designed devices (Ferdek and Kozien, 2013; Guzowski and Sobczyk, 2014; Krawczyk et al., 2018), a personal protection equipment or an appropriate organizational scheme of the company (Ulewicz, 2016; Pacana and Ulewicz, 2017; Maszke et al., 2018). There is social consent for certain risk connected with each kind of work because it is not possible to set up systems which would provide $100 \%$ security at work, but at some moment a border may appear, after crossing which, one could state that specific persons did not meet their obligations in securing safe and hygienic work conditions. This borderline is different for specific kinds of occupations and jobs, however, one could formulate general and abstractive norms which are shared among all kinds of occupations and professions. One should also state that safety and hygiene of work is included into the conceptual range of a term of general protection of work, which a notion with a scope broader than a notion of safety and hygiene of work. General protection of work is an entirety of "legal guarantees for protecting human health and life in a process of work" (Dörre-Kolasa, 2017; Szubert, 1966). 
The purpose of the article is to analyse the institutional system of health and safety at work in Poland based on source of law currently valid in Poland and forming remarks de lege lata and de lege ferenda in this scope.

\section{LEGAL BASIS FOR SAFETY AND HYGIENE OF WORK IN POLAND}

Analyzing the sources of law which is generally applicable in Poland with a view to legal bases of safety and hygiene of work at the beginning the art. 66 of the Constitution of the Republic of Poland of 02 April 1997 (Dz.U. 1997, nr 78, poz. $483 \mathrm{ze} \mathrm{zm}$.) should be indicated, in constitutional legislator states that „Everybody is entitled to safe and hygienic conditions of work. Method of implementation of this law and employer's obligations are defined by the act of law." As it was remarked by B. Banaszak, the right defined in art. 66 of the Constitution of the Republic of Poland is a human right, although at the same time this objective scope is "determined by a fact of performing work", what includes in its notion all persons performing work, and not only employees sensu stricto (Banaszak, 2012). In a context of a notion of general protection of work referred to in the introduction, one should indicate that most employees are covered under general protection (Chobot, 1999). A notion of an employee is perceived differently in the Polish law (Lewandowicz-Machnikowska, 2017), however, from a point of view of protection of safety and hygiene of work defined in the Constitution of the Republic of Poland it is meaningless because, as it was stated above, the constitutional protection is very vast and includes all persons performing work. In the Constitution of the Republic of Poland there are no definitions of safe and hygienic conditions of work, but in a doctrine, they are identified with regulations serving protection of human life and health from hazardous factors arising from work [Banaszak, 2012].

Legal system currently valid in Poland is of multicentric character (Łętowska, 2005), what means that it consists not only from the law established by a Polish legislator, but also the acts of international law and the European Union law. In 1919 at the Congress of Versailles, the International Labour Organization (ILO) was established which congregates representatives of governments, employers, employees and issues acts of law on its own (Łunarski, 2012). In the scope of safety and hygiene of work one should indicate the Convention No. 155 of the International Labour Organization concerning safety, employees' health and work environment. On the ground of the European Union law a key act of law in this scope in the directive of the Council 89/391/EEC of 12 June 1989 regarding introduction of measures for improvement of safety and employees' health in the workplace (Dz.Urz. WE L $183 \mathrm{z}$ 29.06.1989 ze zm.). As D. Dörre-Kolasa points out, this is the so-called framework directive, which outlines "general principles of European standard of work protection”, which next was supplemented by subsequent detailed acts of law of the European Union (Dörre-Kolasa, 2017).

The basic act of law of statutory significance regulating safety and hygiene of work is the Act of 26 June 1974 - Labour Code (Dz.U. 2018, poz. 917 ze zm.), and specifically its Tenth Chapter, titled "Safety and hygiene of work”, including art. 207$237^{15}$, specifying and regulating: basic obligations of an employer, rights and obligations of an employee, issues concerning constructions and work premises, as well as machines and other technical devices, factors and processes of work constituting particular hazard to health or life, preventive health protection, issues 
connected with accidents at work and occupational diseases, trainings, measures of individual protection as well as work clothes and work footwear, activity and organization of service and commission of security and hygiene of work, consultations in the scope of safety and hygiene of work, obligations of bodies supervising the enterprises or other state or local organizational units, authorization concerning specification by ministers of appropriate competence of regulations of safety and hygiene of work in various branches of industry. Therefore, one could state that the regulation in the Labour Code does not include only the general principles of safety and hygiene of work, but also touches on detailed issues. At the same time, one should emphasize that a regulation in a labour code does not cover the entirety of problems of safety and hygiene of work, and especially in an institutional aspect, which often is specified in detailed acts which will be a subject of analysis in a further part of the article.

The Labour Code in the Tenth Chapter contains various statutory authorizations for ministers of appropriate competences, which oblige them to issue regulations, this is why the entirety of laws, concerning safety and hygiene of work also consists of various regulations. As an example one could point out the regulation of the Council of Ministers of 02nd September 1997 regarding the safety and hygiene of work services (Dz.U. 1997, nr 109, poz. 704), a regulation of the Minister of Labour and Social Policy of 26 September 1997 regarding general regulations of safety and hygiene of work (Dz.U. 2003, nr 169, poz.1650), regulations of the Minister of Economy and Labour of 27 July 2004 regarding training in the field of safety and hygiene of work (Dz.U. 2004, nr 180, poz. 1860).

\section{LABOUR PROTECTION BODIES}

On the grounds of the Labour Code the legislator also anticipated the existence of safety and hygiene of work services. Pursuant to art. $237^{11} \S 1$ employer which employs more than 100 employees is obliged to establish safety and work hygiene services, whereas "employer employing up to 100 persons entrusts the performance of safety and work hygiene services to an employee employed at other type of work". Moreover, employer may perform tasks from the competence of safety and work hygiene services provided the following conditions are met: an employee must complete "training necessary for performance of tasks from the competences of safety and work hygiene services”, as well as „employs up to 10 employees or employs up to 20 employees and it is qualified to a group of employees and is qualified for a group of activities, for which a risk category not higher than the third category was established within the meaning of social insurance act on account of accidents at work and occupational diseases". Another organ defined in the Labour Code in the scope of safety and hygiene of work is a committee of safety and hygiene of work which, pursuant to art. $237^{12} \S 1$, an employer is obliged to establish if it employs more than 250 employees. Such committee consists of: „equal numbers of employer's representatives, including the employees of safety and hygiene of work services and a doctor for preventive health care over employees, as well as representatives of employees, including voluntary labour inspector". One should emphasize, however, that the listed organs of protection of safety and hygiene of work are of internal character because they are appointed and they operate within the framework of companies and they are structurally dependent on an employer, and what is more, the safety and hygiene of work services is directly subjected to employer (Dörre-Kolasa, 
2017). Admittedly, a safety and hygiene of work committee can, pursuant to art. $237^{13}$, take advantage - in relation to performance of its tasks - „from expertise or opinion of specialists from outside the workplace”, but only "in cases which had been arranged with an employer and at an employer's cost". Therefore, one should state that the bodies of safety and hygiene of work services which are regulated in the Labour Code, due to its subjugation to an employer, may be inefficient and improperly represent employees' interests.

\section{INSTITUTIONAL PROTECTION OF SAFETY AND SECURITY OF WORK}

Perception and definition of institutionalism varies depending on a field of science (Staniek, 2017). For the purposes of this article under a notion „institutional” one perceives institutions - public organizations, operating within the framework of public administration and performing activities on the behalf and to the benefit of the state (Zimmermann, 2017). In the Polish legal system there are administrative organs, holding administrative power (Zimmermann, 2017; Zdyb and Stelmasiak, 2017), which were appointed for special kind of monitoring and controlling, as well as taking care for adherence to safety and hygiene of work regulations. In order to make the operations of public administration bodies effective in the scope of protection of safety and hygiene of work, it is necessary for public administration to operate effectively (Wytrążek, 2006) based on the sciences on management and praxeology (Kozień, 2017; Kowal, 2015).

In the scope of protection of safety and hygiene of work, in the Polish legal system the important position is occupied by the State Labour Inspectorate which, pursuant to art. 1 of the State Labour Inspectorate Act of 13 April 2007 (Dz.U. 2018, poz. 623 ze zm.) „is a body appointed for monitoring and controlling over observance of the labour code, and especially [among other things - author's comment] of the regulations and principles of regulations and provisions concerning safety and hygiene of work". Here one must consider whether the State Labour Inspectorate is a public administration body. In the doctrine of administrative law it is stated that State Labour Inspectorate is not an element of public administration, but it is a state body (Zimmermann, 2010), which is not an element of state administration, either (Jasińska-Cichoń, 2008). Moreover, it is thought that the State Labour Inspectorate is an institution which performs functions of public administration (Lang, 1999; Muszalski, 1981) and operates in the scope of public administration (Zimmermann, 2010), this is why it is discussed in this article.

Pursuant to art. 10 section 1 item 1, 6, 7 in principio of the State Labour Inspectorate, its competences include, among other items: „monitoring and controlling of adherence to regulations of the labour code, and especially (among other items author's comment) of regulations and principles of safety and hygiene of work", "controlling of products marketed or transferred for use, with a view to meeting by these products of fundamental or other requirements concerning safety and hygiene of work, specified in separate regulations”, „undertaking of activities which are based on prevention and limitation of risks in the labour environment". Moreover, in art. 10 section 2 of the State Labour Inspectorate Act, the legislator awards the State Labour Inspectorate a competence in the scope of supervision and controlling of provision of safe and hygienic conditions of work: „to physical persons performing work based on other principles than an employment contract and self-employed persons performing work in a place designated by an employer or an enterprise, which is not an employer, 
to the benefit of which such work is performed; by entities organizing work performed by natural persons pursuant to principles other than an employment contract, within the scope of voluntary work; to inmates in prisons and juvenile delinquents' homes, who work, as well as to soldiers on active duty, performing works entrusted to them." This monitoring and controlling is also, pursuant to art. 10 section 3 of the State Labour Inspectorate, performed in relation to activities performed by students and pupils, who are not employees. The State Labour Inspectorate is directed by the Head Labour Inspector, whereas the organizational units of the State Labour Inspectorate include: Main Labour Inspectorate, regional labour inspectorates as well as the Professor Jan Rosner Training Center for the State Labour Inspectorate in Wrocław. Bodies of the State Labour Inspectorate are the following: the Head Labour Inspectorate, regional labour inspectors and labour inspectors (Włodarczyk, 2017).

Another body, performing operations from the scope of safety and hygiene of work is the State Sanitary Inspectorate, which, pursuant to art. 1 item 2 of the State Sanitary Inspectorate Act of 14 March 1985 (Dz.U. 2017, poz. 1261 ze zm.) implements tasks from the scope of public health "and especially by performing supervision over the conditions (...) of hygiene of work in work places". Moreover, pursuant to art. 23 section 1 of the State Sanitary Inspectorate Act: "The State sanitary inspector is authorized to control compliance of built structures with hygienic and health requirements, specified in current regulations of law." The State Sanitary Inspectorate is directed by the Head Sanitary Inspectorate who performs his/her tasks using the services of the Main Sanitary Inspectorate and pursuant to art. 8 section 1 of the State Sanitary Inspectorate Act it is the "central body of governmental administration subjected to the minister competent for health matters". Moreover, the field structure of the State Sanitary Inspectorate includes: the state regional sanitary inspector (a body of combined governmental administration in a region), state district sanitary inspector (a body of combined governmental administration in a district) and state border sanitary inspectorate. Next, one must point out the bodies of mining monitoring (President of the Mining Authorities, heads of the regional mining authorities, head of the Specialist Mining Authority), which - pursuant to art. 168 section 1 item 1 of the Act of 04 February 1994 - Geological and Mining Law (Dz.U. 2017, poz. 2126 ze zm.) - perform monitoring over safety and hygiene of work, as well as bodies of marine administration, whose competences, pursuant to art. 42 section 2 item 1 of the Act of 21 March 1991 on marine territories of the Republic of Poland and marine administration (Dz.U. 2018, poz. 2214) include matters of safety of marine travel, however, the inspection of vessels (in reference to ships under the Polish flag) and harbour inspectorate (in reference to ships under foreign ships) has the right of monitoring in the scope of safety and hygiene of work and sanitary and housing conditions.

Apart from that one could also point out the bodies of public administration which, although they do not have safety and hygiene of work sensu stricto awarded into their competences, but they hold authority connected with safety, and therefore may indirectly affect the safety and even the hygiene of work, such as, for example:

- Technical Supervision Authority (Technical Supervision Act of 21 December 2000, Dz.U. 2018, poz. 1351 ze zm.), which performs monitoring and controlling in the scope of regulations and principles in the scope of technical safety, concerning technical devices, as well as including in its scope of operations the operations 
aimed at protection of safety of persons manufacturing and using technical devices and other ones, indicated in the Act;

- architectonic and construction bodies (a starost - head of district, a voivode - head of regional level of state administration, the Head Inspector of Construction Supervision) and construction supervision (district inspector of construction supervision, voivode with the aid a regional inspector of construction supervision, Head Inspector of Construction Supervision) - Act of 7July 1994 - Construction Law (Dz.U. 2018, poz. 1202 ze zm.);

- State Fire Service, which, apart from specific rescue actions serving for protection of safety and hygiene of work also monitors - among other items - observance of fire protection regulations (art. 1 section 2 item 5 of the State Fire Service Act of 24 August 1991, Dz.U. 2018, poz. 1313 ze zm.).

Moreover, using an extensive interpretation, one could also refer to the President of the Rail Transportation Authority (Rail Transport Act of 28 March 2003, Dz.U. 2017, poz. 2117 ze zm.), bodies of Road Transport Inspection (Road Transport Act of 6 September 2001, Dz.U. 2017, poz. 2200 ze zm.), heads of inland shipping authorities (Inland Shipping Act of 21 December 2000, Dz.U. 2017, poz. 2128 ze zm.), organs of Civil Aviation Authority (Aviation Law Act of 3 July 2002, Dz.U. 2018, poz. 1183 ze zm.), as well as State Atomic Energy Agency (Atomic Energy Law of 29 November 2000, Dz.U. 2018, poz. 792 ze zm.).

\section{CONCLUSIONS}

Coming to the conclusions one must state that the system of protection of safety and hygiene of work in Poland is of multicentric character, because this issue is regulated by the international law, the European Union law, the Polish law, which constitute the sources of law which is generally applicable in Poland. Moreover, at a statutory level, the issue of safety and hygiene of work is regulated by numerous acts of law, beginning from the Labour Code which introduces standardized regulations and general provisions, regulating at the same time the detailed issues, ending at many acts of administrative law character, which entrust to them e.g. monitoring or supervision in the scope of safety or safety and hygiene of work or specific actions. De lege lata in the Polish legal order one can perceive, on one hand, a large fragmentation of regulations of administrative law character, but on the other hand, looking at the system, the legislator, wishing to secure specialist protection of safety and/or hygiene of work - in detailed acts creates specialized organs. As a result of the above, performing system analysis one must notice that the legislator wishes to regulate this issue in a holistic manner, establishing general regulations and next, equipping specific bodies of public administration with competences in the scope of safety and hygiene of work. In regulations concerning safety and hygiene of work one can notice intermingling of private law spheres, i.e. rights and obligations in the scope of protection of safety and hygiene of work for private entities (e.g. entrepreneurs) with public law sphere, i.e. competences of specific bodies of public administration in the scope of safety and hygiene of work. It should be emphasized, though, that a notion of safety and hygiene of work should be perceived in a functional manner, because securing only safety in a given scope it is also secured at work, and securing only safety one often provides indirectly the hygiene of work or other activities. However, for the bodies of public administration to act properly in this scope, it is necessary for them to operate effectively. De lege ferenda one should consider 
whether the State Labour Inspection should not be clearly defined as a body of public administration, what surely would have contributed to its more efficient operation also in a scope of safety and hygiene of work. Moreover, an issue of protection of safety and hygiene of work should be standardized in detailed acts of law of public administration character so that to strengthen the protection of safety and hygiene of work especially in spheres in which the risk to safety and hygiene of work is particularly high. One can also consider the clear introduction of competences in the scope of protection of safety and hygiene of work in specialized bodies of public administration so that a holistic system of protection of safety and hygiene of work could be established in Poland.

\section{REFERENCES}

Banaszak B., 2012. Konstytucja Rzeczpospolitej Polskiej. Komentarz. / Constitution of the Republic of Poland. Comment. Wydawnictwo C.H. Beck, Warszawa, Poland.

Chobot A., 1999. Ochrona pracy / Labour protection. Wydawnictwo Poznańskie, Poznań, Poland. [in Polish]

Dörre-Kolasa D. [in:] Baran K. (ed.), 2017. Prawo pracy i ubezpieczeń społecznych / Labour and social insurance law. Wolters Kluwer, Warszawa, Poland. [in Polish]

Ferdek, U., Kozien, M.S., 2013. Simulation of application of FGM piezoelectric actuators for active reduction of beam vibrations. Acta Phys. Pol. A, 123, 10441047. DOI: 10.12693/APhysPolA.123.1044

Guzowski A, Sobczyk A., 2014. Reconstruction of Hydrostatic Drive and Control System Dedicated for Small Mobile Platform. ASME - Fluid Power Systems Technology, 8th FPNI Ph.D Symposium on Fluid Power, art.V001T05A012.

Jasińska-Cichoń A., 2008. Ustawa o Państwowej Inspekcji Pracy. Komentarz. / The Act on the National Labour Inspectorate. Comment. Wolters Kluwer, Warszawa, Poland. [in Polish]

Kowal W., 2015. Sprawność organizacji. Emocjonalne, behawioralne i finansowe efekty działań marketingowych $w$ ocenie skuteczności $i$ efektywności przedsiębiorstwa. / The efficiency of the organization. Emotional, behavioural and financial effects of marketing activities in assessing the effectiveness and efficiency of the company. Wydawnictwo Uniwersytetu Ekonomicznego we Wrocławiu, Wrocław, Poland. [in Polish]

Kozień E., 2017. Praxeological Concept of Evaluation of Undertaken Actions. [in:] Jaki A., Mikuła B., 2017. Knowledge - Economy - Society. Management in the face of contemporary changes and dilemmas, Cracow University of Economics, Cracow, Poland.

Krawczyk, J., Sobczyk, A., Stryczek, J., Walczak, P., 2018. Tests of New Methods of Manufacturing Elements for Water Hydraulics. Mater. Res. Proc., 5, 200-205.

Mazur, M., Mikova, K., 2016. Impact resistance of high strength steels. Mater. TodayProc. 3, 1060-1063. DOI: 10.1016/j.matpr.2016.03.048

Muszalski W., 1981. Państwowa Inspekcja Pracy / National Labour Inspectorate. Przegląd Ustawodawstwa Gospodarczego, 10-12, 222. [in Polish]

Lang J., 1999. Rozważania nad prawnym położeniem Państwowej Inspekcji Pracy / Considerations on the legal position of the National Labor Inspectorate. Acta Universitatis Vratislaviensis, 2154, 212. [in Polish] 
Lewandowicz-Machnikowska M. [in:] Baran K. (ed.), 2017. Prawo pracy i ubezpieczeń społecznych / Labour and social insurance law. Wolters Kluwer, Warszawa, Poland. [in Polish]

Łętowska E., 2005. Multicentryczność współczesnego systemu prawa i jej konsekwencje / Multicentricity of the contemporary legal system and its consequences. Państwo i Prawo, 4/2005, 3-10. [in Polish]

Łunarski J., 2012. Zarządzanie jakością. Standardy i zasady / Quality management. Standards and principles. Wydawnictwo WNT, Warszawa, Poland. [in Polish]

Maszke, A., Dwornicka, R., Ulewicz, R., 2018, Problems in the implementation of the lean concept at a steel works - Case study. MATEC Web Conf., 183, art. 01014.

Pacana, A., Ulewicz, R., 2017. Research of Determinants Motiving to Implement the Environmental Management System. Pol. J. Manag. Stud. 16, 165-174.

Pobedza, J., Sobczyk, A., 2013. Modern Coating Used in High Pressure Water Hydraulic Components. Key Engineering Materials, 542, 143-155.

Radzyminska-Lenarcik, E., Ulewicz, M., 2014. The use of 1-alkylimidzoles for selective separation of zinc ions in the transport process across a polymeric inclusion membrane. Physicochem. Probl. Miner. Process., 50, 131-142.

Staniek Z., 2017. Ekonomia instytucjonalna. Dlaczego instytucje są ważne / Institutional economy. Why institutions are important. Difin, Warszawa, Poland.

Szabracki, P., Lipinski, T., 2014. Influence of sigma phase precipitation on the intergranular corrosion resistance of X2CrNiMoN25-7-4 super duplex stainless steel. METAL 2014: $23^{\text {rd }}$ Int. Conf. Metallurgy and Materials. Ostrava, Tanger, 476481.

Szubert W., 1966. Ochrona pracy / Labour protection. PWN, Warszawa, Poland.

Ulewicz, M., Lesinska, U., Bochenska, M., 2010. Transport of lead across polymer inclusion membrane with p-tert-butylcalix[4]arene derivative. Physicochem. Probl. Miner. Process., 44(1), 245-256.

Ulewicz, R., 2016. Quality Management System operation in the woodworking industry. Int. Conf. "Path Forward for wood products: a global perspective". Zagreb, WoodEMA, i.a., 51-56.

Walczak, P., Sobczyk A., 2014. Simulation of water hydraulic control system of Francis turbine. ASME - Fluid Power Systems Technology, $8^{\text {th }}$ FPNI Ph.D Symposium on Fluid Power, art. V001T04A001. DOI: 10.1115/FPNI2014-7814

Włodarczyk M. [in:] Baran K. (ed.), 2017. Prawo pracy i ubezpieczeń społecznych społecznych / Labour and social insurance law. Wolters Kluwer, Warszawa, Poland. [in Polish]

Wytrążek W., 2006. Sprawność działania administracji publicznej w Polsce w warunkach decentralizacji / The efficiency of public administration in Poland in the conditions of decentralization. Wydawnictwo KUL, Lublin, Poland. [in Polish]

Zdyb M., Stelmasiak J. (ed.), 2016. Prawo administracyjne / The administrative law. Wolters Kluwer, Warszawa, Poland. [in Polish]

Zimmermann J., 2010. Prawo administracyjne / The administrative law. Wolters Kluwer, Warszawa, Poland. [in Polish]

Zimmermann J., 2016. Prawo administracyjne / The administrative law. Wolters Kluwer, Warszawa, Poland. [in Polish] 